DOI: 10.2478/auseur-2021-0009

\title{
Spatial Dimensions of Regional Innovativeness in Romania
}

\author{
Szilárd MADARAS \\ PhD, Sapientia Hungarian University of Transylvania (Cluj-Napoca), \\ Faculty of Economics, Socio-Human Sciences and Engineering, Miercurea Ciuc \\ e-mail: madarasszilard@uni.sapientia.ro \\ Lehel GYÖRFY \\ PhD, Babeş-Bolyai University, \\ Faculty of Economics and Business Administration, Cluj-Napoca \\ e-mail: lehel.gyorfy@econ.ubbcluj.ro
}

\begin{abstract}
This paper contains the analysis of regional innovation performance in the NUTS 2 regions of Romania, based on the European Innovation Scoreboard evaluation for 2011 and 2019, and the identification of the most significant influencing factors of county-level R\&D activity, for the 1997-2018 period. The Regional Innovation Index (RII) provides a profound characterization for Romanian regions regarding their innovation performance, which was studied using the GIS (Geographic Information System) methodology in relation with the regional R\&D activity, GDP per capita, and entrepreneurship innovation. In the following, the Romanian R\&D activity is analysed at the county level. The influencing factors of R\&D expenditures and employment in Romanian counties were studied based on two panel regression models and using exogenous variables, for economic development, entrepreneurship, education, and infrastructure.
\end{abstract}

Keywords: regional innovation, geographic information system, entrepreneurship innovation, R\&D

\section{Introduction}

The innovative performance of NUTS 2 regions in the European Union was assessed by the European Commission using the Regional Innovation Scoreboard's methodology. ${ }^{1}$ Due to the complexity of innovation, in addition to the economic importance, there are regional-level policy, academic, institutional, entrepreneurial, infrastructural, and labour market implications and conditions. Previous studies have focused on the determining factors of regional innovation

1 https://ec.europa.eu/growth/industry/policy/innovation/regional_en. 
employment and activities (Silva et al. 2021), regional innovation potential in the EU regions (Źółtaszek-Olejnik 2017), the regional labour market structure's impact on innovation activities (Roper-Love 2006), the role of local institutions and administration in the Italian regional innovation performance (Arbolino et al. 2019), the typologies of European regions according to the knowledge base, and R\&D activities and innovation potential (Blažek-Kadlec 2019).

The regional innovation activities have a significant policy implication, as Silva et al. (2021) suggest, and depend on regional R\&D investments and expenditures, as well as on the innovation activities of SMEs. Based on an EU database containing 238 regions, Silva et al. (2021) investigated regional innovation. They developed two panel models describing the regional innovation impact on high-tech employment and firm innovation caused by new market sales. They suggest that the conditions for regional high-tech employment (for example, in knowledge-intensive services) include lifelong learning and a share of population with tertiary education, also depending on business sector investments in R\&D and the SMEs' innovative collaborations and public-private co-publications.

Arbolino et al. (2019) have studied the annual innovation outcome by regions in the Italian regions, including a set of explanatory variables, of which we highlight regional GDP per capita, the share of micro-enterprises, and motorway kilometres per inhabitant as an infrastructural factor.

Well-qualified human capital and R\&D financial resources were identified by Żółtaszek and Olejnik (2017) as having significant effects on regional innovation potential in the European Union, while in Zygmunt (2020) tertiary education graduates are included in the explanatory model of firms' innovation activities in Poland and the Czech Republic.

The wide array of tools adopted in the regional methods of analysis examine the spatial differences regarding the regional indicators, such as the GIS (Geographic Information System) methodology, on the one hand and identify the influencing factors of an economic situation, using in general panel type regression models, which include regional explanatory variables across a period of time on the other hand. The GIS (Geographic Information System) was used by Goschin and Druica (2020) to perform the spatial analysis of Romanian regions, focusing on the changes in entrepreneurial activity at the county level, and by Goschin (2020) to identify, based on economic activities, the NUTS 2 and NUTS 3 levels of regional specializations and to identify the spatial differences in terms of employment in the settlements of Harghita County (Madaras 2019). The panel data model methodology was used in Arbolino et al. (2019) in the determining factor analysis of regional innovation performance, and panel regression models were used to identify the influencing factors of regional competitiveness in Györfy and Madaras (2017), using a set of exogenous variables based on the European Commission's Regional Competitiveness Index (RCI) pillars. 
In this paper, we examine the following questions: Which are the most important economic characteristics of the most innovative NUTS 2 regions in Romania? Which are the influencing factors of regional R\&D (research and development) employment and expenditures in the counties of Romania? The structure of the paper is as follows: the introduction contains the review of the most appropriate studies; the first chapter focuses on the GIS analysis of innovations in the Romanian NUTS 2 regions; the second chapter contains the panel regression estimations for the regional innovation employment and expenditures in the Romanian counties. These are followed by the discussion of the results, and, finally, the conclusions are formulated.

\section{GIS (Geographic Information System) Analysis of Regional Innovativeness in Romania}

The Regional Innovation Index (RII), provided by the European Innovation Scoreboard, indicates a decrease in all NUTS 2 regions in the 2011-2019 period. The highest values for both years appear in the Bucharest-Ilfov Region (0.287 and 0.251), while the lowest in the South-West Oltenia Region (0.146) for the year 2011 and in the South - Muntenia Region (0.09) for the year 2019. The order of regions also changed: in 2011, the second and third were the South-East Region (0.198) and the North-West Region (0.189), while in 2019 the West Region (0.159) and the North-West Region (0.144) (Figure 1a-b).

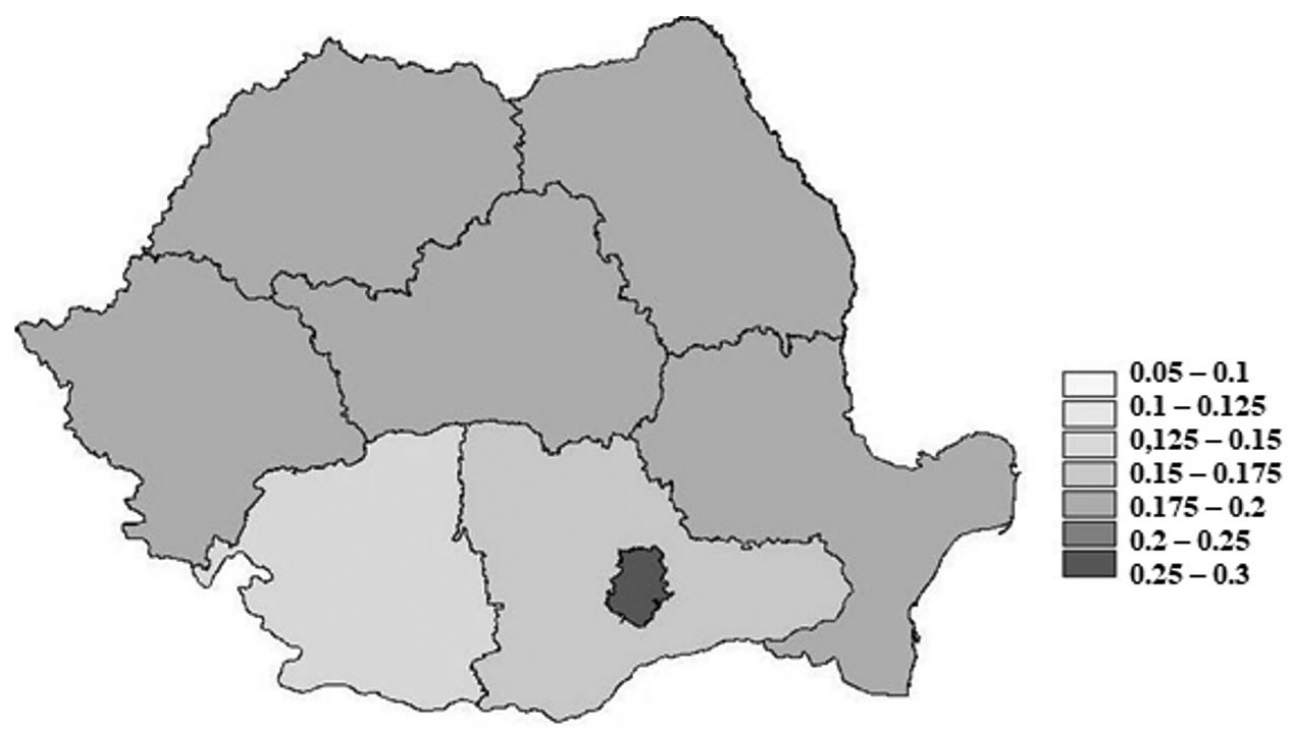

Figure 1a. Regional Innovation Index in 2011 


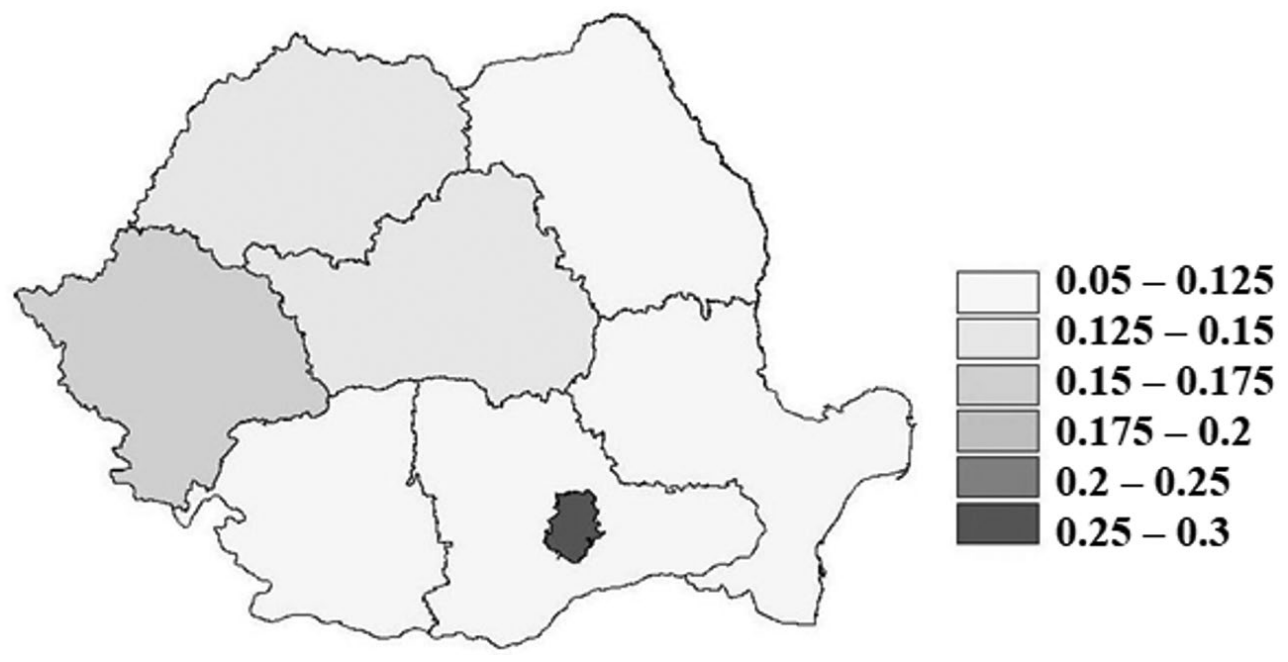

Source: European Innovation Scoreboard ${ }^{2}$

Figure 1b. Regional Innovation Index in 2019

In the following, we will examine the R\&D employees and expenditures in the Romanian regions in 2012 and 2018. In both years, the highest number of R\&D employees were in the Bucharest-Ilfov Region (16,972 and 17,700 people), more than in all the other regions combined. A relatively large decrease in the SouthWest Oltenia Region (57.67\%) and in the South - Muntenia Region $(22.55 \%$ ), a growth of $43.55 \%$ in the Centre Region and of $30.91 \%$ in the West Region have led to a new structure in 2018, when the Centre Region (3,715 people) came second and the West Region (2,393 people) third (Figure $2 a-c)$.

2 Data source: Regional Innovation Scoreboard 2019, the Regional Profiles for Romania; available at: https://ec.europa.eu/info/research-and-innovation/statistics/performance-indicators/ regional-innovation-scoreboard_en. 


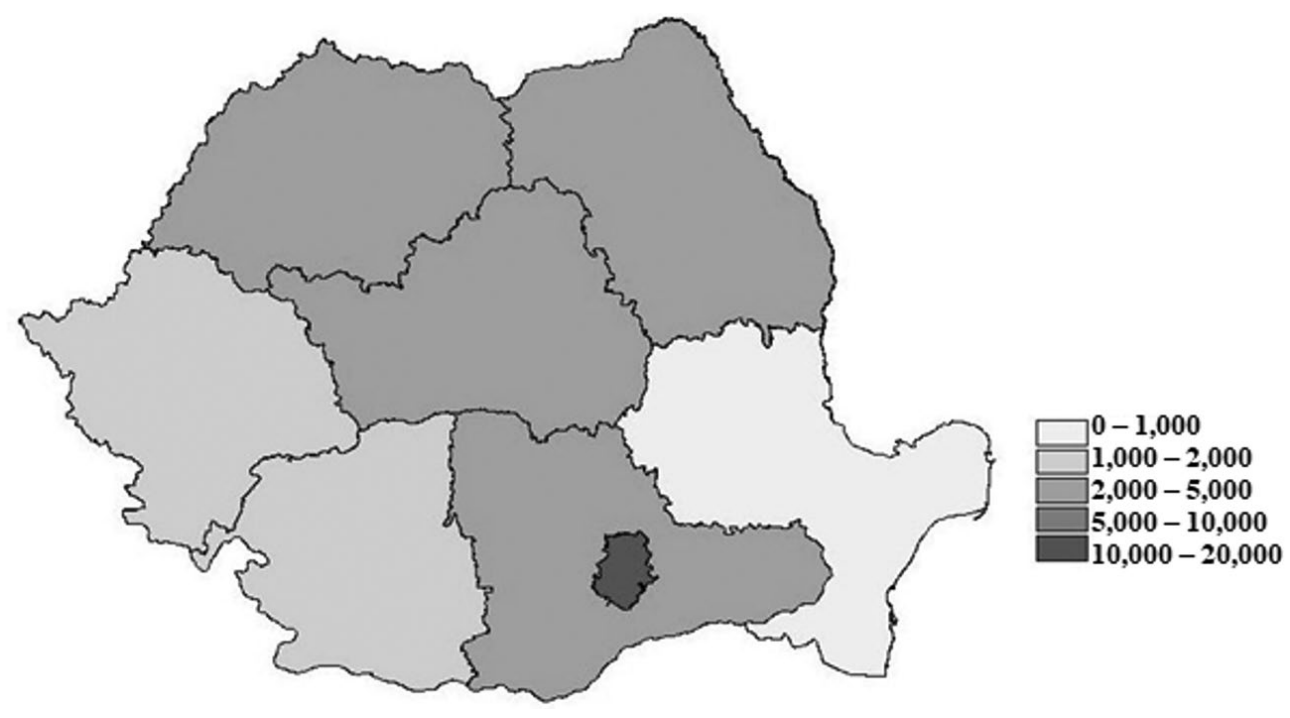

Figure 2a. R\&D employees in 2012

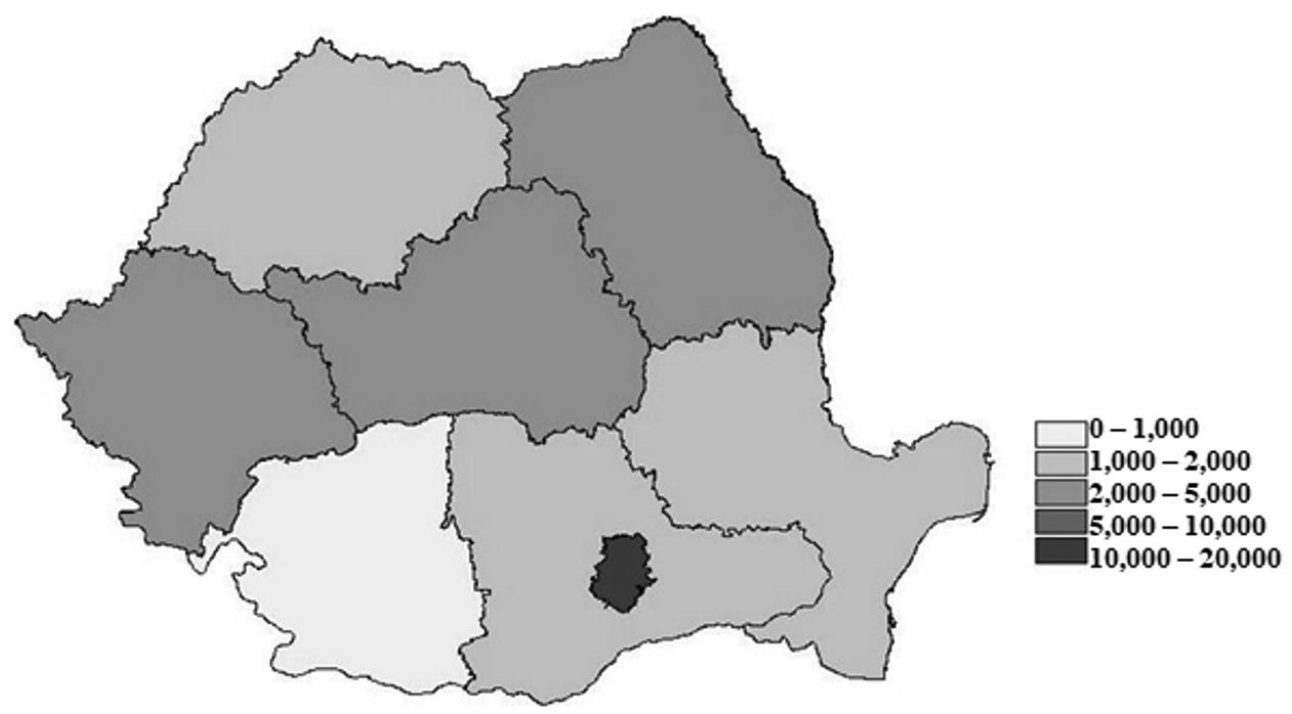

Figure 2b. $R \& D$ employees in 2018 


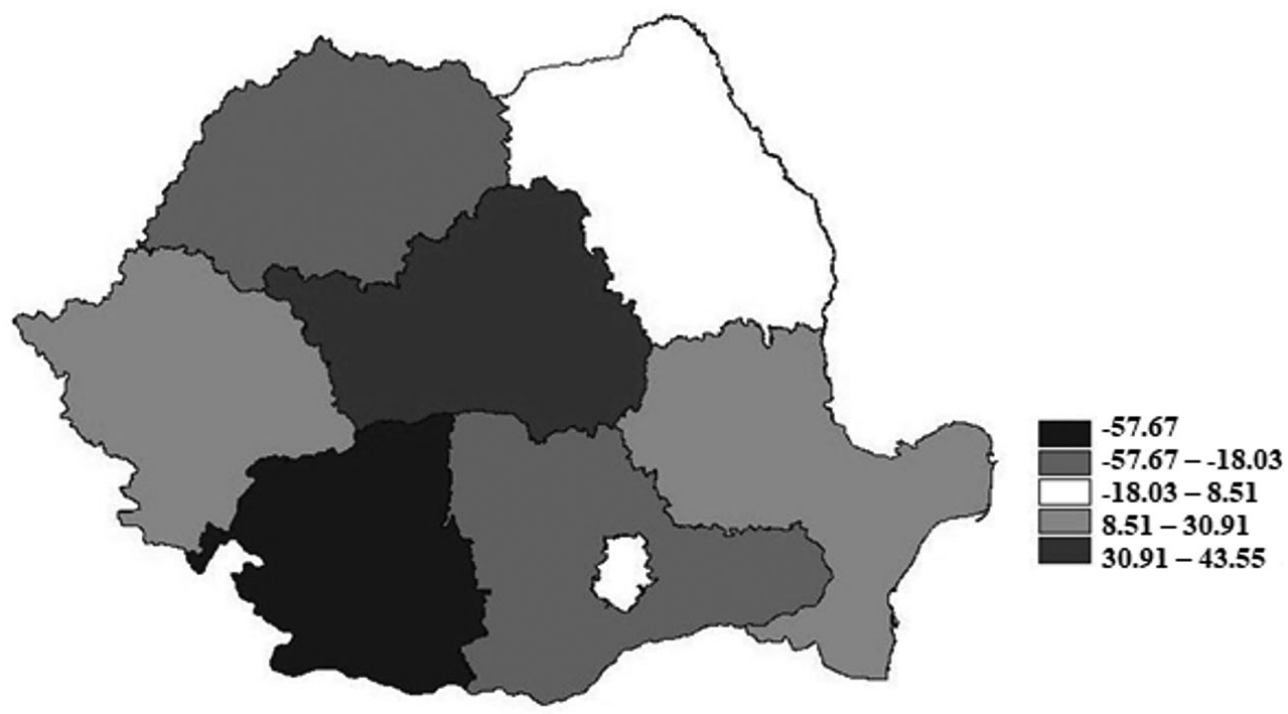

Source: own calculation based on the INSSE database ${ }^{3}$

Figure 2c. R\&D employees - difference between 2012 and 2018

The highest R\&D expenditure was registered in the Bucharest-Ilfov Region for both years (1,575,613 and 3,001,082 thousand lei); in 2018, this value is $69.72 \%$ more than all the other regions combined (Figure $3 a-c$ ).

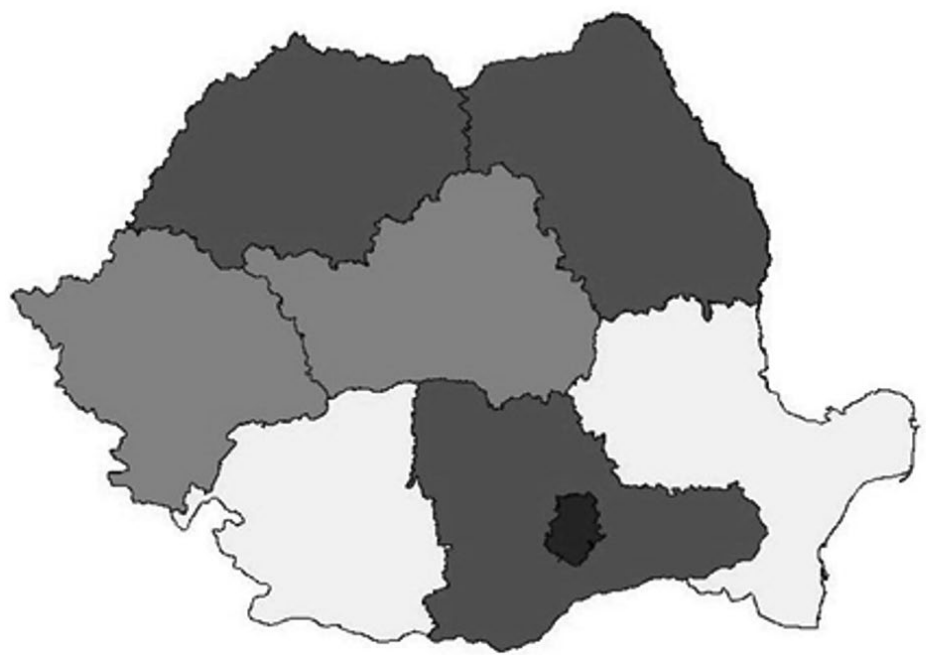

Figure 3a. $R \& D$ expenditure (thousand lei) in 2012

3 Data source: CDP102E - employees from research; development activity from: http://statistici. insse.ro:8077/tempo-online/\#/pages/tables/insse-table. 


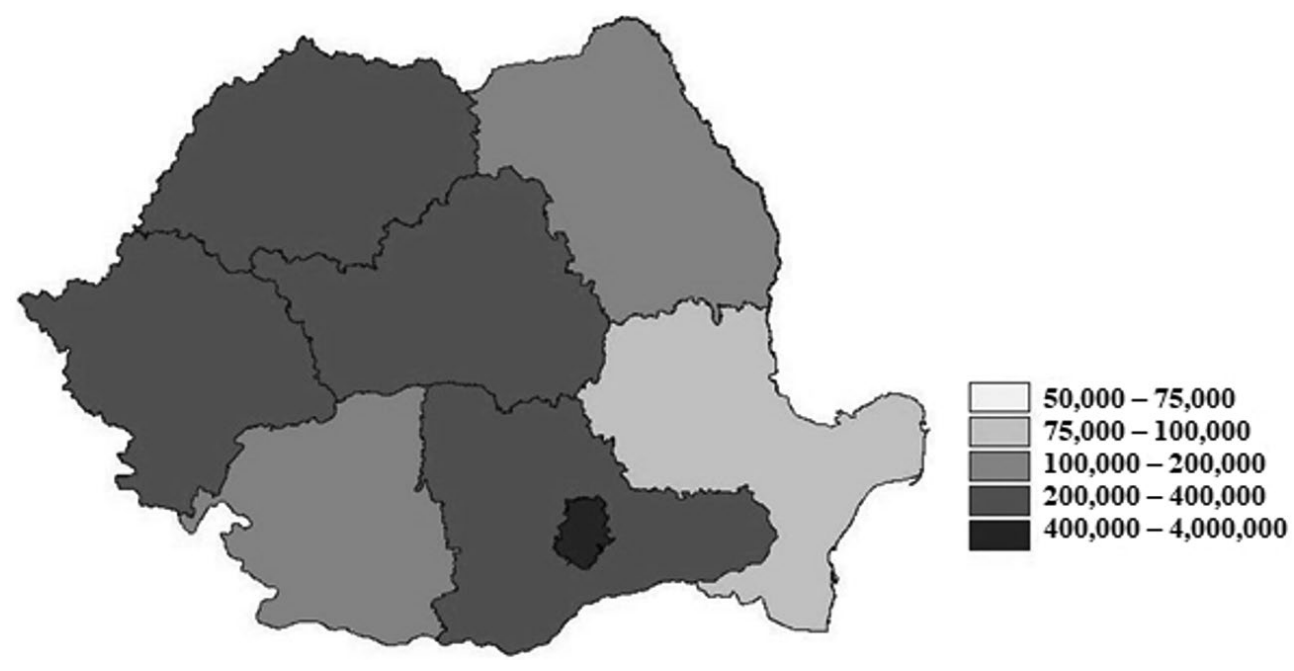

Figure 3b. R\&D expenditure (thousand lei) in 2018
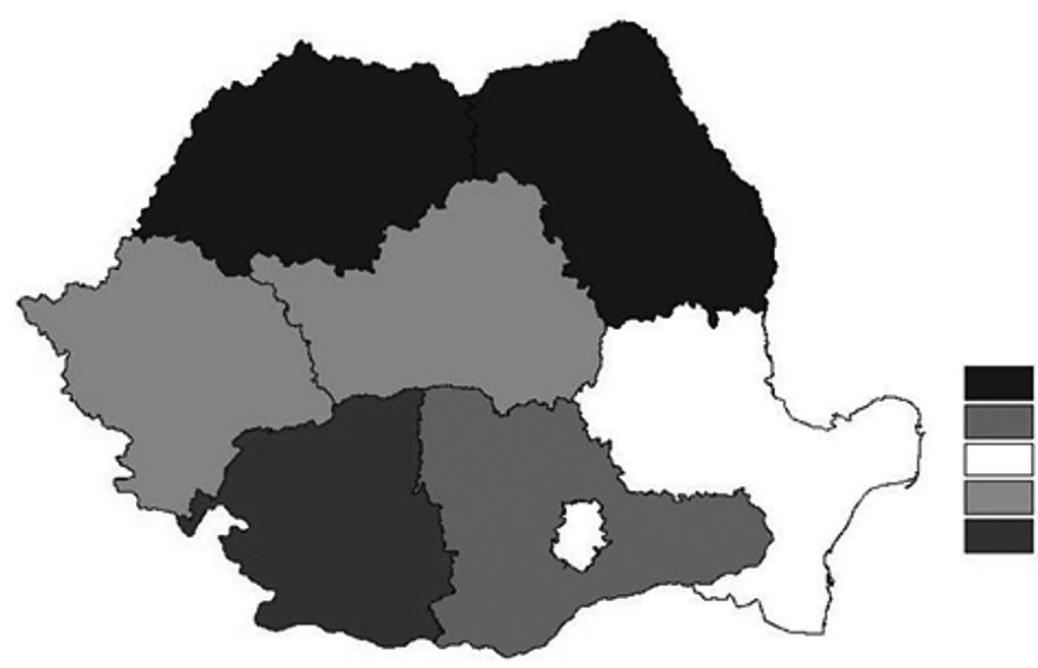

$-21.42--16.24$

$-16.24-9.75$

$9.75-90.47$

$90.47-139.85$

$139.85-193.23$

Source: own calculation based on the INSSE database ${ }^{4}$

Figure 3c. R\&D expenditure - difference between 2012 and 2018

4 Data source: CDP104B - total expenditure from research and development activity; available at: http://statistici.insse.ro:8077/tempo-online/\#/pages/tables/insse-table. 
The Bucharest-Ilfov Region is the most developed region in Romania: the regional GDP per capita was 68,933.4 thousand lei in 2012 and 111,159.5 thousand lei in 2018. Significant increase was observed in the South-West Oltenia Region $193.23 \%$ in plus), the West Region (139.85\% in plus), and the Centre Region $(117.23 \%$ in plus), and a decrease in the North-West Region (21.42\% in minus) and the NorthEast Region (16.24\% in minus). In 2012, the second and the third places were occupied by the South - Muntenia Region (331,591 thousand lei) and the NorthWest Region (298,616 thousand lei), while in 2018 by the West Region $(374,229$ thousand lei) and the South - Muntenia Region (363,924 thousand lei).

The structure of R\&D employees and expenditures partially follows those of the Regional Innovation Index (RII) from 2019.

The regional GDP per capita shows the same order in both years: the BucharestIlfov Region, the West Region, the Centre Region, followed by the others. We can see a parallel with this order and that of the Regional Innovation Index (RII) (Figure 4a-b).

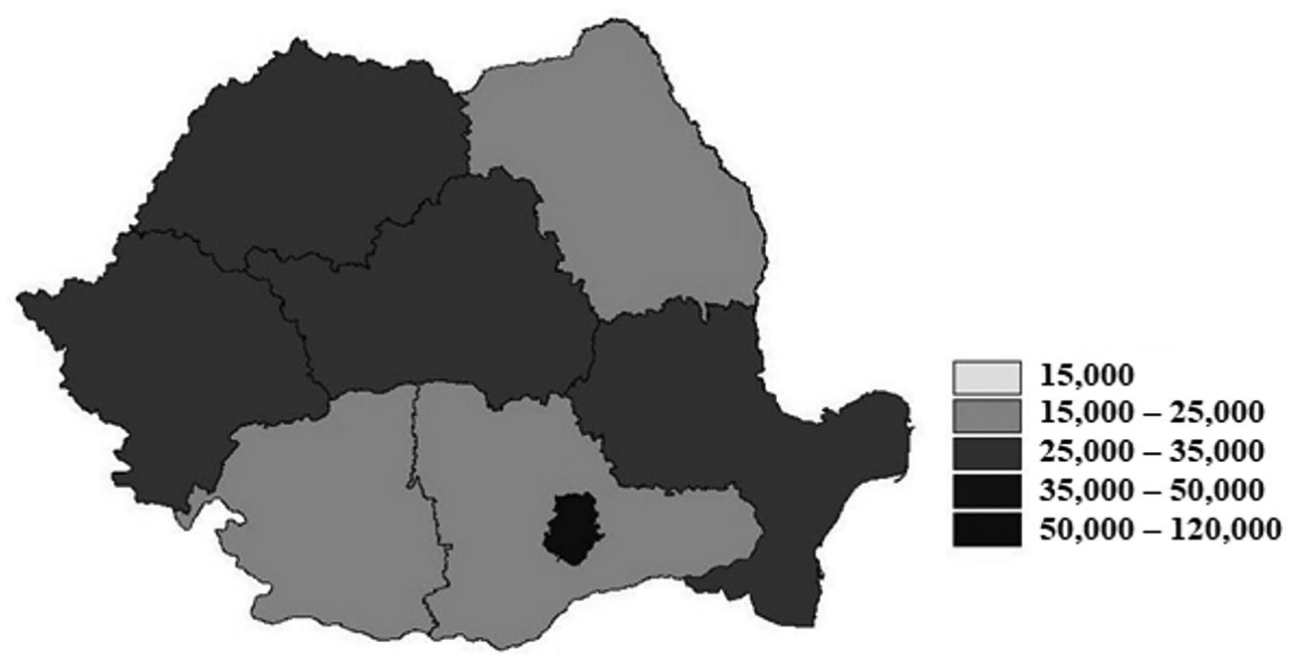

Figure 4a. GDP per capita (lei) in 2012

In 2012, the highest share of innovative enterprises was registered in the SouthEast Region (36.48\%) followed by the North-East Region (32.17\%); however, the regional order changed in 2018: the highest became the Bucharest-Ilfov Region $(25.47 \%)$ followed by the North-West Region $(21.07 \%)$. In 2012, the share of innovative enterprises in all regions was above 12\%, while in 2018 relatively low values were observed in the West Region (3.98\%), the South-West Oltenia Region $(4.42 \%)$, and the South - Muntenia Region (6.33\%) (Figure 5a-b). 

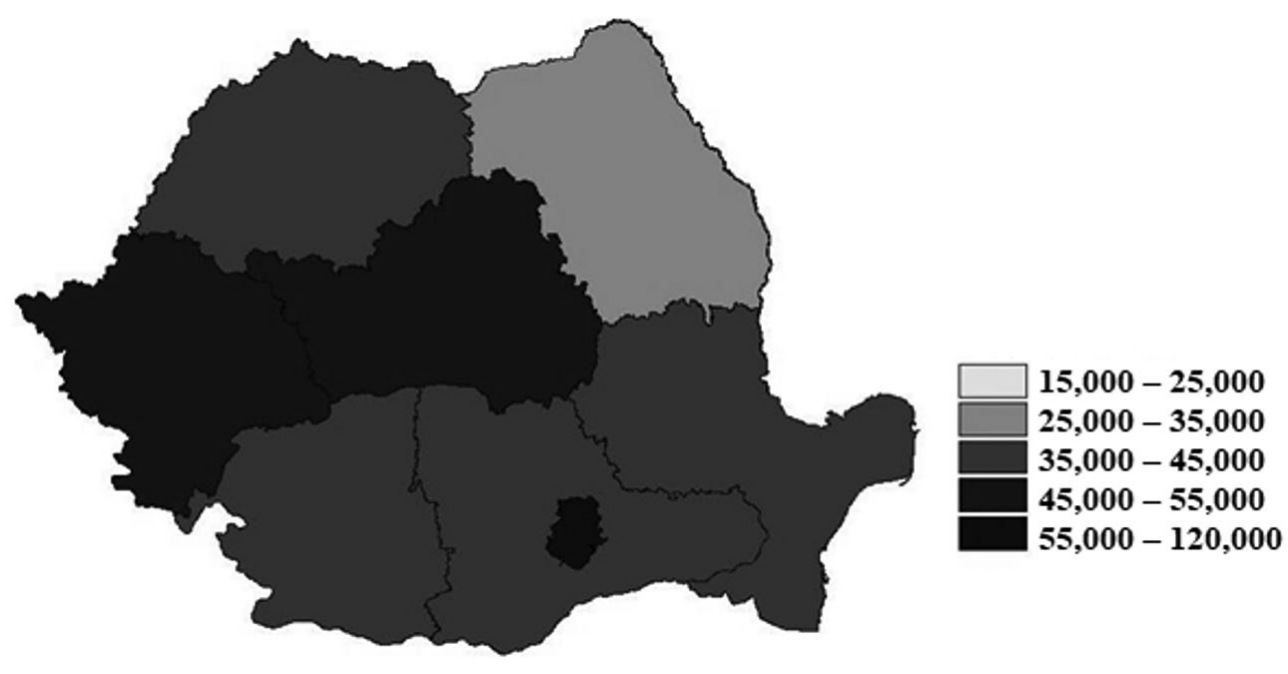

Figure 4b. GDP per capita (lei) in 2018

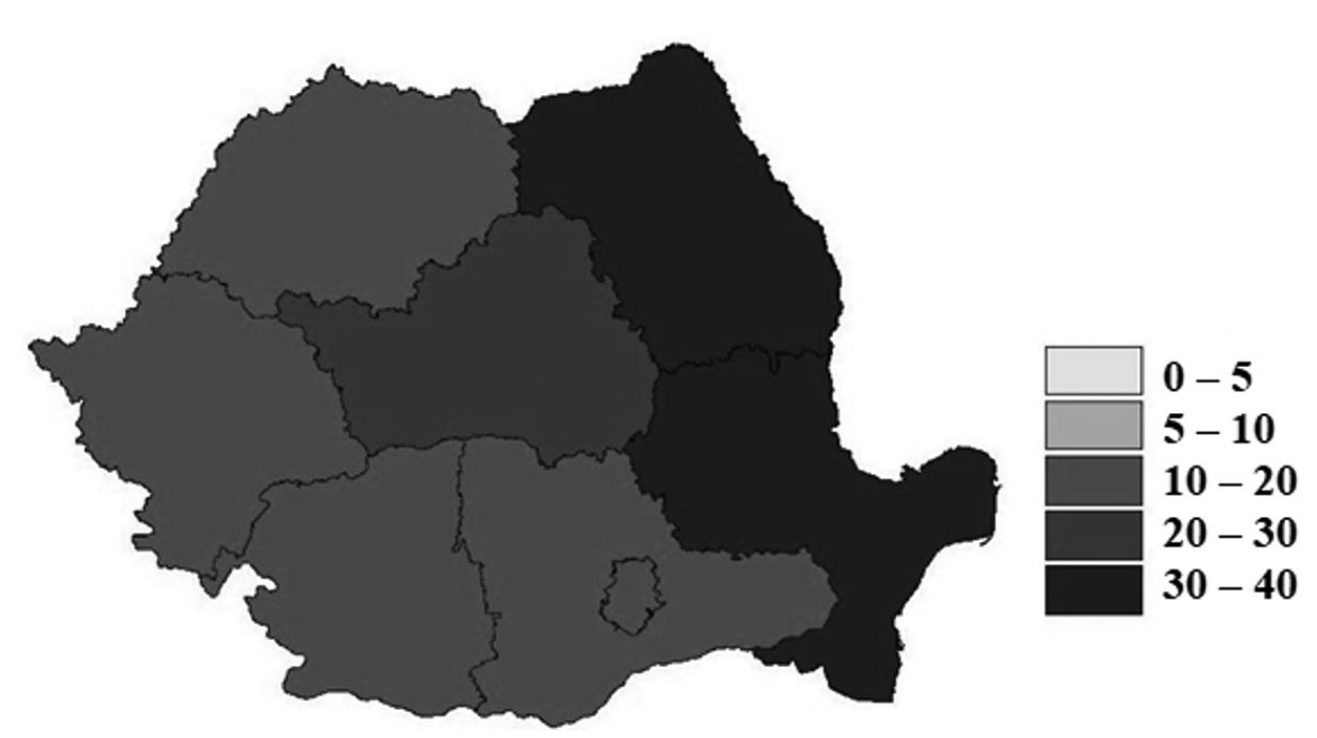

Figure 5a. The share of innovative enterprises in Romanian regions in 2012

5 Data source: CON103H - Regional gross domestic product (RGDP) per inhabitant; available at: http://statistici.insse.ro:8077/tempo-online/\#/pages/tables/insse-table. 


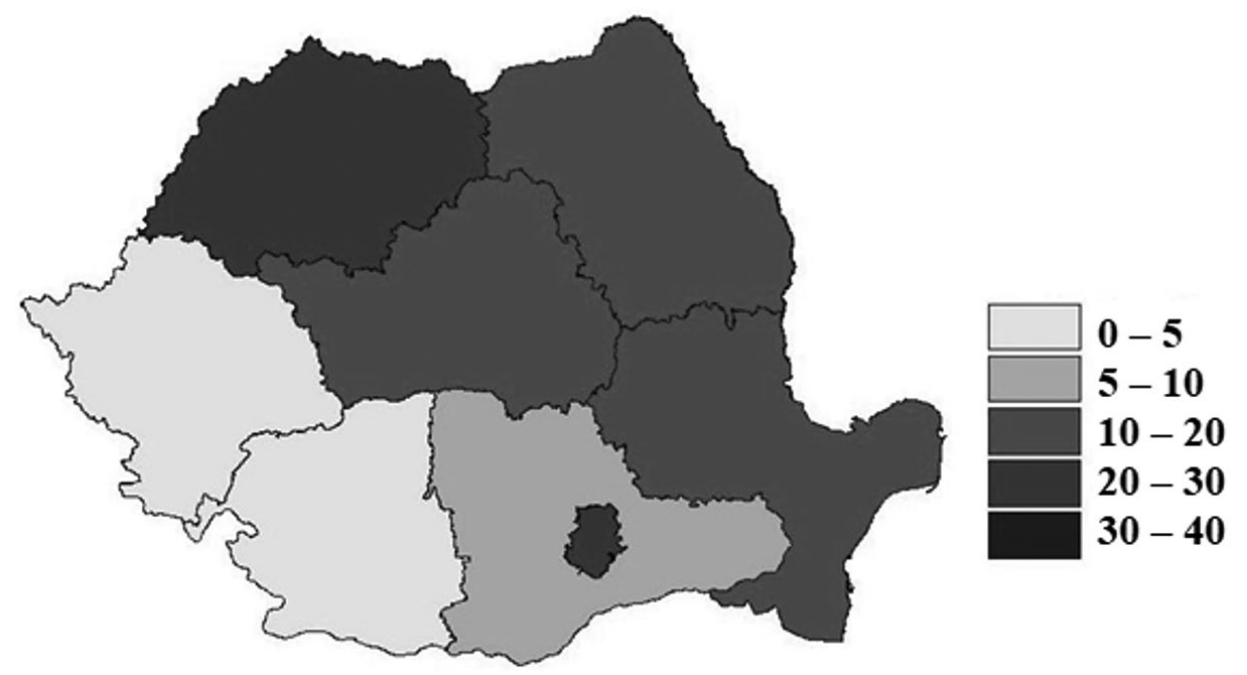

Source: own calculation based on the INSSE database ${ }^{6}$

Figure 5b. The share of innovative enterprises in Romanian regions in 2018

\section{Factors Influencing Regional R\&D Employment and Expenditure}

In the next part, we set up a Romanian county-level database to study the most significant influencing factors of regional R\&D employment and expenditure. The data for the 1997-2018 period were taken from the National Statistical Institute, also including six indicators as follows:

1. regional R\&D employees per 1,000 inhabitants (RDemp),

2. logarithmic values of regional $R \& D$ expenditure (RDexpt),

3. GDP per capita (in 1,000 lei) (GDPpc),

4. number of enterprises on 1,000 inhabitants (entrpc),

5. proportion of secondary school graduates from the total (educsec),

6. proportion of modern roads from the total (modinfr).

These indicators contain different characteristics of regional development: firstly the R\&D dimension, secondly the economic development and entrepreneurial willingness, thirdly the education and entrepreneurial, and fourthly the regional infrastructure. We need to mention here that other regional indicators (as the proportion of tertiary graduates in education, the proportion of Internet users among the population, etc.) would have been useful in our estimation, but we omitted them due to lack of data for the studied period. Also

6 Data source: INO101C - Innovative and non-innovative enterprises; available at: http://statistici. insse.ro:8077/tempo-online/\#/pages/tables/insse-table. 
due to lack of data, Giurgiu, Ialomița, and Mehedinți counties were eliminated from the database (Table 1).

Dachin and Postoiu (2015) studied the Romanian county-level R\&D expenditures in relation with the GDP per capita, using Pearson's correlation and confirming a direct link between them. Also, in Arbolino et al. (2019), the regional GDP per capita was included in their regional innovation's panel model.

In Roper and Love (2006), among other regional labour market indicators, the tertiary education level was included as explanatory among the firms' achieved innovation estimations, as well as in Zygmunt (2020). Similar to our data, in Arbolino et al. (2019), the regional proportion of micro-enterprises and of motorways was used as entrepreneurial and infrastructural variables.

The estimations were performed based on the final form of the panel database, containing 858 observations for the 39 counties and the span of 22 years (the 19972018 period) (Table 1).

Table 1. The statistics of regional indicators

\begin{tabular}{lccccc}
\hline & Obs. & Mean & Std. Dev. & Min. & Max. \\
\hline RDexp & 858 & 8.675876 & 2.0099 & 3.78419 & 14.33754 \\
\hline RDemp & 858 & 1.381488 & 2.136829 & .0021572 & 14.30862 \\
\hline GDPpc & 858 & 16.55678 & 13.70346 & .6843671 & 108.564 \\
\hline entrpc & 858 & 17.93532 & 8.096328 & 6.366763 & 60.24409 \\
\hline educsec & 858 & 42.15496 & 7.937213 & 18.24592 & 61.78968 \\
\hline modinfr & 858 & 32.75466 & 16.47025 & 11.39169 & 100 \\
\hline
\end{tabular}

Source: own calculation based on the INSSE database

Table 2. The regional R\&D employment and cost model statistics

\begin{tabular}{|l|c|c|c|c|}
\hline & \multicolumn{4}{|c|}{ Coefficients } \\
\cline { 2 - 5 } & $\begin{array}{c}\text { Fixed-effects } \\
\text { (within) } \\
\text { regression }\end{array}$ & $\begin{array}{c}\text { Random-effects } \\
\text { GLS regression }\end{array}$ & $\begin{array}{c}\text { Fixed-effects } \\
\text { (within) } \\
\text { regression }\end{array}$ & $\begin{array}{c}\text { Random-effects } \\
\text { GLS regression }\end{array}$ \\
\hline Dependent & RDemp & RDemp & RDexp & RDexp \\
\hline Variable & & & & \\
\hline RDemp & & & $.258691^{* * *}$ & $.3345463^{* * *}$ \\
\hline GDPpc & $-.0164201^{* * *}$ & $-.0220177^{* * *}$ & -.0004744 & -.0007774 \\
\hline entrpc & $.0414945^{* * *}$ & $.0567405^{* * *}$ & $.0562351^{* * *}$ & $.0604068^{* * *}$ \\
\hline educsec & $-.0117829^{* * *}$ & $-.0159419^{* * *}$ & $.0139609^{* * *}$ & $.0103363^{* *}$ \\
\hline modinfr & .003447 & $.0061849^{* *}$ & $.0945378^{* * *}$ & $.0930452^{* * *}$ \\
\hline cons & $1.292936^{* * *}$ & $1.197819^{* * *}$ & $-183.0691^{* * *}$ & $-180.0947^{* * *}$ \\
\hline F & 106.54 & & 170.66 & \\
\hline Prob $>\mathrm{F}$ & 0.0000 & & 0.0000 & \\
\hline
\end{tabular}




\begin{tabular}{|l|c|c|c|c|}
\hline & \multicolumn{4}{|c|}{ Coefficients } \\
\cline { 2 - 5 } & $\begin{array}{c}\text { Fixed-effects } \\
\text { (within) } \\
\text { regression }\end{array}$ & $\begin{array}{c}\text { Random-effects } \\
\text { GLS regression }\end{array}$ & $\begin{array}{c}\text { Fixed-effects } \\
\text { (within) } \\
\text { regression }\end{array}$ & $\begin{array}{c}\text { Random-effects } \\
\text { GLS regression }\end{array}$ \\
\hline Wald chi2 & & 48.12 & & 904.66 \\
\hline Prob > chi2 & & 0.0000 & & 0.0000 \\
\hline
\end{tabular}

Source: own calculation based on the INSSE database ${ }^{7}$

** Significant at the 0.05 level.

*** Significant at the 0.01 level.

The regional R\&D employment (RDemp) in the fixed-effects model is positively influenced by the number of enterprises per 1,000 inhabitants (entrpc) and negatively influenced by GDP per capita (GDPpc); the share of secondary school graduates (educsec) is at the $1 \%$ level. The random-effects model's results confirmed these results and also included the infrastructural indicator (share of modern roads, modinfr) at the $5 \%$ level (Table 2).

The regional R\&D expenditure (RDexp) in the fixed effects-model is positively influenced by the regional R\&D employment (RDemp), the number of enterprises per 1,000 inhabitants (entrpc), the share of secondary school graduates (educsec), and the share of modern roads (modinfr) at the $1 \%$ level. The random effectsmodel's results confirmed the above positive significant influencing factors, except for one difference: the educational indicator is significant at the $5 \%$ level (Table 2).

\section{Discussions}

The spatial analysis of Romanian regional R\&D activities highlighted the concentration into the Bucharest-Ilfov Region, which seems to be an essential characteristic, as Dachin and Postoiu (2015) stated it. The high values of the regional innovation index in some regions seem to be related more to the economic development than to the innovation activities of the enterprises. This trend does not mean the lack of innovative opportunities in the counties placed in the low RII value regions. For example, the Ministry of Research, Innovation, and Digitalization has established and operates a wide network of innovation and technology transfer entities (technology incubators, IT centres, technology transfer centres in sectors such as energy, construction, food industry, biotechnology, tourism, environmental protection, and others) in 15 counties in Romania. ${ }^{8}$

7 Data source: http://statistici.insse.ro:8077/tempo-online/\#/pages/tables/insse-table.

8 Source: https://www.research.gov.ro/ro/articol/4728/sistemul-de-cercetare-infrastructuride-cercetare-infrastructura-de-inovare-si-transfer-tehnologic-entitati-de-inovare-si-transfertehnologic. 
The regional GDP per capita has significant influence on regional R\&D employment, but it does not have impact on the regional R\&D costs. This could be interpreted to mean that the regional R\&D activity does not depend on the economic development in a given county, but R\&D employment is related to it. The importance of regional GDP per capita with regard to regional innovation performance was highlighted in Dachin and Postoiu (2015) and Arbolino et al. (2019).

The secondary education influences the regional R\&D employment negatively in both models, but this is not the standard indicator used in literature, as the share of tertiary (higher) education was replaced by this indicator due to lack of data. As Roper and Love (2006) and Zygmunt (2020) suggest, tertiary education graduates are more appropriate explanatory variables for regional innovation. The role of education played in the regional R\&D process could not be properly included in our estimations due to lack of data on the tertiary education level for the studied period (1997-2018).

The importance of infrastructure in regional economic development was studied in Györfy and Madaras (2017), where the proportion of modern roads in the counties of the Central Region was used, and in Arbolino et al. (2019), where the share of motorways in regions was assumed to have an impact on regional innovation. In the present estimation, the regional R\&D employment and costs are also positively influenced by this infrastructural indicator although other R\&D-related infrastructural indicators (Internet connection, entrepreneurship digitalization, etc.) were omitted from our database due to lack of data on the Romanian regions.

Our results highlight the importance of regional entrepreneurship with regard to R\&D activity, as also found in Arbolino et al. (2019). Local firms may get involved in new product development research activities with local/academic institutes, as a public-private cooperation. The analysis of Romanian enterprises' innovation activity between 2012 and 2018 pointed out that the proportion of innovators has grown, as well as the cooperation with other companies or institutes, although there were several obstructive factors concerning innovation such as the lack of financial resources, of well-trained personnel, and others (Madaras 2020: 122-129).

\section{Conclusions}

Regional innovation index (RII) values and the spatial structure in the Romanian NUTS 2 regions in 2011 and 2019 were presented using the GIS technology. Regional innovation in Romania has significant spatial differences and, although it reveals a concentrated nature in the most developed regions, local examples of successful R\&D cooperation could be found in all over the country. The GIS analysis of the Romanian regions indicates that R\&D employment and expenditure and GPD per capita partially follow the RII's spatial distribution, while enterprises' 
innovation activities are independent from them. The most outstanding position in terms of regional innovation in Romania was occupied by the Bucharest-Ilfov Region, and in 2019 the second and third places were taken by the West Region and the North-West Region.

The Romanian county-level R\&D number of employees and the amount of expenditures were studied in a dataset including 39 counties for the 1997-2018 period. The results indicate a significant positive effect on R\&D employment by the number of enterprises per 1,000 inhabitants and the share of modern roads and a negative effect by the regional GDP per capita and the share of secondary school graduates. As Roper and Love (2006) and Zygmunt (2020) indicate, regional innovation activity depends on tertiary graduates, but, due to lack of data on this indicator for the studied period, we made our estimation using the share of secondary graduates.

In the second estimation, regional $R \& D$ expenditures depended on $R \& D$ employees, the relative number of enterprises, the share of secondary graduates, and the share of modern roads - at the 1\% significance level. Our results are in line with the findings of Żółtaszek and Olejnik (2017) and Arbolino et al. (2019) and suggest that the well-trained employees, the potential of private sector, the level of education, and the infrastructure lead to prosperous R\&D activities in Romanian regions.

The limitations of this study are as follows: the Regional Innovation Scoreboard's methodology includes further dimensions such as lifelong learning, scientific activities, sales to new market segments, product innovations, etc., which - partially due to lack of data - were not included in our explanatory models of regional R\&D activity. Future research needs to be performed to discuss all these features of innovation in the Romanian regions.

\section{References}

ARBOLINO, Roberta-BOFFARDI, Raffaele-DE SIMONE, Luisa. 2019. Which Are the Factors Influencing Innovation Performances? Evidence from Italian Cohesion Policy. Social Indicators Research 146(1-2): 221-247.

BLAŽEK, Jiri-KADLEC, Vojtech. 2019. Knowledge Bases, R\&D Structure and SocioEconomic and Innovation Performance of European Regions. Innovation: The European Journal of Social Science Research 32(1): 26-47.

DACHIN, Anca-POSTOIU, Constantin. 2015. Innovation and Regional Performance in Romania. Theoretical and Applied Economics XXII(2): 55-64.

EUROPEAN COMMISSION. 2019. Regional Innovation Scoreboard 2019 Methodology Report. 
GOSCHIN, Zizi. 2020. Economic Specialization of Romanian Regions and Counties. Insights Drawn from Static and Dynamic Location Quotients. Romanian Journal of Economics 50(1): 84-112.

GOSCHIN, Zizi-DRUICA Elena. 2020. Spatial Changes in Entrepreneurship in Relation to Economic Crisis and Recovery. Insights from Romanian Counties. Proceedings of the International Conference on Applied Statistics 2(1): 161-177. DOI: 10.2478/icas-2021-0015.

GYÖRFY, Lehel-MADARAS, Szilárd. 2017. Factors Influencing Nuts3 Level Regional Competitiveness in Center Region, Romania. A Panel Regression Analysis. Romanian Journal of Regional Science 11(2).

MADARAS, Szilárd. 2019. The Spatial Differences of Employment between the Settlements of Harghita County. Acta Universitatis Sapientiae, European and Regional Studies 15: 65-82.

2020. Innováció menedzsment. Cluj-Napoc: Presa Universitară Clujeană.

ROPER, Stephen-LOVE, H. James. 2006. Innovation and Regional Absorptive Capacity: The Labour Market Dimension. Annals of Regional Science 40(2): 437447.

SILVA, Pedro-PIRES, Sara Moreno-TELES, Filipe. 2021. Explanatory Models of Regional Innovation Performance in Europe: Policy Implications for Regions. Innovation: The European Journal of Social Science Research 34(4): 609-631.

ŻÓŁTASZEK, Agata-OLEJNIK, Alicja. 2017. Regional Effectiveness of Innovation Leaders and Followers of the EU NUTS 0 and NUTS 2 Regions. Lodz Economics Working Papers 8/2017. The Faculty of Economics and Sociology, University of Lodz.

ZYGMUNT, Aleksandra. 2020. Do Human Resources and the Research System Affect Firms' Innovation Activities? Results from Poland and the Czech Republic. Sustainability 12(6): 2519.

\section{Online Sources}

*** https://ec.europa.eu/growth/industry/policy/innovation/regional_en.

*** https://ec.europa.eu/info/research-and-innovation/statistics/performanceindicators/regional-innovation-scoreboard_en.

*** https://www.research.gov.ro/.

*** http://statistici.insse.ro:8077/tempo-online/\#/pages/tables/insse-table. 